\title{
COVID-19 and clinical nutrition. Why is it important?
}

\section{COVID-19 y la nutrición clínica. ¿Por qué es importante?}

\author{
Enrique Cervantes-Pérez, ${ }^{1 *}$ Gabino Cervantes-Guevara² and Martha C. Martínez-Soto-Holguín ${ }^{1}$ \\ ${ }^{1}$ Instituto Nacional de Ciencias Médicas y Nutrición "Salvador Zubirán", Department of Clinical Nutrition Sciences, Mexico City; ²Universidad de \\ Guadalajara, Centro Universitario del Norte, Department of Well-being and Sustainable Development, Jalisco. Mexico
}

In December 2019, in Wuhan, China, numerous cases of community-acquired pneumonia caused by a new virus, which was named SARS-CoV-2, were reported. In June of this year, the incredible figure of 7 million cases all over the world was exceeded. Multiple comparisons with other coronavirus pandemics have been formulated; however the impact of the current one remains uncertain.

The presence of comorbidities and old age are almost invariably associated with a poor nutritional status and sarcopenia, and it is therefore necessary to early identify nutritional risk and the presence of malnutrition. Given the lack of studies assessing nutritional risk in patients infected with SARS-CoV-2, these considerations can be applied to all of them. ${ }^{1,2}$ There are various tools for nutritional assessment in non-critical hospitalized patients, with the main ones being the 2002 Nutritional Risk Screening, the Malnutrition Universal Screening Tool, the Global Subjective Assessment and the Nutrition Risk in Critically ill scale for critically ill patients.

Whether immunonutrition plays a role in the present pandemic remains to be determined. Numerous articles have been published explaining the role of nutrition in the immune system and that $\mathrm{T}$ cells weakening due to thymus dysfunction contributes to a reduction in the generation of native $T$ cells, inflammation associated with aging, ${ }^{3}$ and to a poor micronutrimental status. ${ }^{4}$ Gombart et al. identified potential synergistic relationships of micronutrients, including vitamins $A, D, C, E, B_{6}$, and $B_{12}$, folates, copper, iron, zinc and selenium, to meet complex needs of the immune system. ${ }^{5}$

Nutritional therapy is aimed at, among other things, increasing host immune response. Every effort should be aimed at identifying patients with nutritional risk, avoiding or limiting undernourishment in patients with COVID-19, and ensuring adequate nutritional support in hospitalized patients with malnutrition.

\section{References}

1. Volkert D, Beck AM, Cederholm T, Cruz-Jentoft A, Goisser S, Hooper L, et al. ESPEN guideline on clinical nutrition and hydration in geriatrics. Clin Nutr. 2019;38:10-47.

2. Cederholm T, Barazzoni R, Austin P, Ballmer P, Biolo G, Bischoff SC et al. ESPEN guidelines on definitions and terminology of clinical nutrition. Clin Nutr. 2017;36:49-64.

3. Franceschi C, Garagnani P, Parini P, Giuliani C , Santoro A. Inflammaging: A new immune-metabolic viewpoint for age-related diseases. Nat Rev Endocrinol. 2018;14:576-590.

4. Maggini S, Pierre A, Calder P. Immune function and micronutrient requirements change over the life course. Nutrients. 2018;10:1531.

5. Gombart AF, Pierre A, Maggini S. A review of micronutrients and the immune System-Working in harmony to reduce the risk of infection. Nutrients. 2020;12:236.

\section{Correspondence:}

${ }^{*}$ Enrique Cervantes-Pérez

E-mail: enrique.cervantes@academico.udg.mx
DOI: 10.24875/GMM.M20000412
Gac Med Mex. 2020;156:357

Contents available at PubMed www.gacetamedicademexico.com 0016-3813/C 2020 Academia Nacional de Medicina de México, A.C.. Published by Permanyer. This is an open access article under the CC BY-NC-ND license (http://creativecommons.org/licenses/by-nc-nd/4.0/). 